\title{
İş Güvencesizliğinin İş Performansına Etkisinde Örgütsel Kimliğin Aracılık Etkisi
}

\author{
DOI: 10.26466/opus.584655 \\ * \\ $\underline{\text { Kenan Orçanl1 }}^{*}$ - Mustafa Bekmezci** ${ }^{*}$ Zafer Mehmet Frrat*** \\ * Öğr.Gör.Dr., Milli Savunma Üniversitesi, Kara Harp Okulu, Ankara. \\ E-Posta: kenanorcanli@gmail.com \\ ORCID: $\quad$ 0000-0001-5716-4004 \\ ** Doç.Dr., Toros Üniversitesi, İISBF, Mersin \\ E-Posta: mustafa.bekmezci@toros.edu.tr ORCID: 0000-0002-1206-690X \\ *** Dr., Milli Savunma Üniversitesi (Misafir Öğretim Elemanı), Ankara \\ E-Posta: mzaferfirat@hotmail.com \\ ORCID: 0000-0003-3303-0305
}

Öz

Günümüzde birçok araştırmacı tarafından iş performansı kavramı üzerinde, iş güvencesizliği ve örgütsel kimlik kavramlarının etkisinin olduğu bilinmektedir. Ulusal ve uluslararası yazında yapılan araştırmalarda iş performansı, iş güvencesizliği ve örgütsel kimlik kavramlart ile bu kavramlar arasındaki ikili ilişkilerin araştırıldığg görülmüş, fakat iş performansı ile iş güvencesizliği olguları arasındaki ilişkide örgütsel kimlik kavramının aracılık etkisinin araştırılmadığg tespit edilmiştir. Bu kapsamda yapılan çalışma, iş performansı olgusu üzerinde iş güvencesizliğinin etkisinin ve bu etkide örgütsel kimlik kavramının aracılık rolünün olup olmadı̆̆ını saptamayı amaçlamaktadır. Çalışmada kullanılan veriler, Kırıkkale ilindeki Pirinç Fabrikası Müdürlü̈̆̈̈ personeline uygulanan üç adet ölçekten oluşan anket formu ile toplanmış ve kurulan modelin analizi Yapısal Eşitlik Modellemesi (YEM) ile test edilmiştir. Çalışma evrenini Kırıkkale ilindeki Pirinç Fabrikası Müdürlüğü’nde görev yapan 105 çalışan oluşturmuştur. Yapılan çalışma, örgütsel kimlik olgusunun, iş güvencesizliği ile iş performansı arasındaki ilişkide kısmi aracılık rolü olduğunu göstermektedir. Kısmi aracılık etkisi olan değişkenlerin arasındaki ilişkiler ile ilgili olarak yapılan Sobel Testi sonucunda iş güvencesizliği ile iş performansı değişkenleri arasında anlamlı bir ilişkinin olduğu ve dolayısıyla örgütsel kimlik olgusunun iki değişken arasında kısmi aracılık etkisine sahip olduğu görülmüsstür.

Anahtar Kelimeler: $\dot{I}_{s ̧}$ Performansı, İş Güvencesizliği, Örgütsel Kimlik.

1 Bu çalışma, 02-04 Mayıs 2019 tarihleri arasında Korkut Ata Üniversitesinde düzenlenen 18. Uluslararası İ̧̧letmecilik Kongresinde sözlü olarak sunulan ve kongre kitabında tam metin olarak yayımlanan genişletilmiş özetin, gelen eleştiriler ve öneriler doğrultusunda geliştirilmiş halidir. 


\title{
The Mediation Effect of Organizational Identity in the Relationship between Job Insecurity and Job Performance
}

\begin{abstract}
Today, it is known by many researchers that organizational identity and job insecurity has an impact on job performance. As a result of research conducted in domestic and foreign literature; it was determined that relations between job performance, job insecurity and organizational identity were investigated, but it was not determined that the mediation effect of organizational identity was investigated in the relationship between job performance and job insecurity. The aim of this study is to determine whether organizational identity have a mediation role in the effect of job insecurity on job performance or not. The data used in the study were gathered with the three scales applied to the personnel of the Brass Factory Directorate in Kirnkkale province and the analysis of the model was tested with Structural Equation Modeling (SEM). The study population consisted of 105 employees working in the Brass Factory Directorate in Kirikkale province. As a result of this study, it was concluded that organizational identity has had a partial mediation role in the relationship between job insecurity and job performance. As a result of the Sobel Test conducted in relation to the relationships between the variables with partial mediating effect; it was confirmed that there was a significant relationship between job insecurity and job performance and that organizational identity had a partial mediation effect between two variables.
\end{abstract}

Keywords: Job Performance, Job Insecurity, Organizational Identity. 


\section{Giriş}

Günümüzde üretim ve pazarlama faaliyetleri, teknolojinin küresel etkileşimi artırması nedeniyle küresel bir nitelik kazanmıştır. Bu bağlamda dünya üzerindeki bilgi ve sermaye akımlarının üzerindeki engellerin kaldırılması ile her işletme küresel ölçekte dünyanın herhangi bir yerindeki yatırım ve pazar fırsatlarını değerlendirebilir duruma gelmiştir. Fakat bu durum, rekabeti de artırmıştır. Bu gelişmelere ayak uyduramayan işletmeler rakipleri ile mücadele etmekte zorlanmakta ve zaman içinde küçülerek yok olmaktadır. Bu kapsamda işletmelerin yapısındaki bu önemli değişimler, işten çıkarmalar, çalışma hayatında esneklik uygulamaları, iş süreçlerindeki hızlı değişim gibi faktörler çalışanlarda iş güvencesi anlamında önemli bir kaygı kaynağı olmaktadır. Bu durum çalışanların iş performansını olumsuz etkilemektedir. Çalışanların iş güvencesi ile ilgili kaygılarını azaltma noktasında gerek akademik alanda gerekse uygulama sahalarında önerilen en önemli argümanlardan birisi örgütsel kimlik olgusudur.

Literatürde iş performansı, iş güvencesizliği ve örgütsel kimlik kavramları ile bu kavramlar arasındaki ikili ilişkinin birçok kez araştırıldığı görülmüş̧tür. Ancak çalışanların iş güvencesizliğinin performanlarına etkilediği ve bu ilişkide örgüt kimliğinin nasıl bir etki yaptığı ile ilgili çalışmanın ise yapılmadığı tespit edilmiştir. Bu kapsamda yapılan çalışma, iş güvencesizliğinin çalışanların iş performanslarına etkisinde örgütsel kimliğin aracılık etkisi olup olmadığını belirlemeyi amaçlamaktadır. Çalışanların algıladığı iş güvensizliğinin iş performansını etkileyeceği ve dolayısıyla örgütün performansının da bundan etkileneceği değerlendirilmiş, örgütsel kimlik olgusunun aracılık etkisinin tespit edilmesinin yazına katkı sağlayacağı düşünülmüştür.

\section{Kavramsal Çerçeve}

Araştırmanın değişkenleri ile ilgili olarak yazında yapılan ampirik çalışmalarda farklı modeler kullanılmaktadır. Fakat bu üç değişken arasındaki ilişkinin Yapısal Eşitlik Modellemesi (YEM) ile yeterince araştırılmadığı görülmüştür. Bu kapsamda, YEM'in bu ilişkiyi ortaya koymada önemli bir analiz yöntemi olduğu düşünülmektedir. Özellikle iş 
güvencesizliğinin çalışanların iş performansına etkisinde örgütsel kimliğin aracılık etkisinin saptanmasında YEM'in kapsamlı çıkarımlar sunması beklenmektedir. Bu kapsamda, çalışmada kullanılan olgular ve bu olgular arasındaki ilişki ile ilgili kuramsal bilgi, çalışmanın devam eden bölümlerinde sunulmuştur.

\section{İş Güvencesizliği}

İş güvencesizliğinin ulusal ve uluslararası yazında oldukça çeşitli tanımları bulunmaktadır. İş güvencesizliği, kişinin işini kaybetmesi yönündeki tehdit algısı ve bununla ilgili endişeleridir (Greenhalgh ve Rosenblatt, 1984). Sverke ve akadaşları (2004)'na göre, iş güvencesizliği, kişinin mevcut işinin devamlılığı ile ilgili olası tehlikeyi algılamasıdır. Ancak tanımların birçoğunda araştırmacılar tarafından iş güvencesizliği kavramının öznel bir algı, gelecek hakkında duyulan kaygı ile ilgili bir durum olduğu, istem dışı gerçekleştiği ve güçsüzlükle ilişkili olduğu üzerinde durulmaktadır (Greenhalg ve Rosenblatt, 1984; Sverke ve Hellgren, 2002; Ashford ve Bobko, 1989). Bu kapsamda Özaman ve arkadaşları (2006, s.46)'na göre bireyin istediği iş güvencesi düzeyi ile gerçek güvence durumu arasındaki fark, iş güvencesizliği algı düzeyini belirlemektedir ve bu durumda kişinin işten çıartılma korkusunun algılanmasındaki farkın açılamasında çok sayıda olasılıktan söz etmek mümkündür.

İş güvencesizliği olgusunun ortaya çıkmasında çalışanın işini kaybedeceğinden haberdar olması (bilişsel) ve nesnel koşula karşılık gelen tepki durumunun (duygusal) belirlenmesi önemli bir husustur. Bir kişinin, işini kaybedeceğinden haberdar olması o kişinin bilinç durumunu gösterir, fakat bu bilinç durumunun korku ya da kaygı gibi olumsuz duygusal etkileri hakkında bilgi vermez. Nesnel koşula karşılık gelen tepkinin bilinmesi önemlidir. Çünkü tehdit durumunda oluşacak tepkinin boyutu sosyal yapıdan bağımsız değildir ve sosyal koruma, iş güvencesizliğinin sonuçlarını değiştirebilir (Özaman Boya ve Demiral, 2006, s.46).

İş güvencesizliğinin unsurları, belirsizlik, çalışma koşullarının değişkenliğinden kaynaklanan tehdit algısı ve kaygı olup, nedenleri ise bireysel, örgütsel, ekonomik ve hukuki olarak sıralanabilir (Çakır, 2007, 
s.120,126). Güvencesizliğin en belirgin olduğu dönem belirsizlik dönemidir. Herhangi bir olayın meydana gelip gelmeyeceğinin bilinmemesi belirsizlik olarak adlandırılmaktadır. Belirsizlik durumunda kişi, işine devam edip etmeyeceğini ve işteki pozisyonuyla ilgili olarak kendisine gelecekte ihtiyaç duyulup duyulmayacağını bilmemektedir (De Witte, 1999, s.156). Günümüzün hızlı bilgi ve teknoloji değişimi ve küreselleşme ortamında işyerlerinin kapanması ve işten çıkartmaların artması dikkat çekmektedir. Bu durum da çalışanlar tarafından tehdit olarak algılanmaktadır. Çünkü birçok çalışan işini kaybetmekte, birçoğu da, işsizlik tehlikesi ile karşı karşıya kalmaktadır. Belirsizliğin yüksek olduğu bir ortamda, iş güvencesizliği de artmaktadır. Çakır, (2007, s.118), işini kaybetme kaygısını, iş güvencesizliği olarak tanımladığı çalışmasında iş güvencesizliği yaşayan kesimleri sınıflandırmıştır. Bu kapsamda iş güvencesizliğinin en çok yaşandığı kesim kısmi süreli çalışanlar, geçici çalışanlar ve mevsimlik işçiler gibi sürekli iş sözleşmesine sahip olmayanlardır. İş güvencesizliği riski altındaki ikinci kesim, uzmanlık ve teknik bilgi gerektiren işlerde belirli sürelerle çalışanlar, tele çalışanlar gibi yaptığı işi farklı örgütlerde sürdüren kişilerdir. Üçüncü grupta ise işe yeni başlayanlar ve deneme süreci içinde yer alanlar bulunmaktadır. İş güvencesizliğinin bir diğer biçimini, belirsiz süreli ve güvenceli bir işte çalışmakta iken, organizasyonel değişimler sonucunda güvencesiz bir konuma getirilme sonucunda işini kaybetme riski ile karşı karşıya kalanlar yaşamaktadır. Diğer taraftan düşük eğitim düzeyi (Schaufeli, 1992) ile yönetim tarzı ve iletişim şekli (Storseth, 2006) de iş güvencesizliğinin nedenleri arasında gösterilmektedir (Aktaran; Dereli, 2012). Bu kapsamda; eğitim düzeyi düşük olan kişilerin, iş güvencesi olmayan işlerde çalıştığ1 ifade edilmektedir. İnsan odaklı yaklaşımlar ile çalışanlara önem verildiğini gösteren iletişim tarzı ise iş güvencesizliğini azaltmaktadır.

İş güvencesine ilgili yapılan çalışmalarda, iş güvencesizliği olgusunun çalışanlar üzerindeki etki ve sonuçları ile bunların iş tutum ve davranışlarına etkisi genellikle ihmal edilmektedir. İş güvencesi-güvencesizliği, sadece yasal düzenlemeler kapsamında ve ekonomiye etkileri açısından ele alınmamalıdır. İşini kaybetme endişesi yaşayan insanların, yaşadığı kaygıdan kaynaklanan bireysel ve örgütsel sonuçlarının olduğu da bilinmelidir. Bu kapsamda iş güvencesizliğinin etkilediği tutum ve davranışlar genel olarak Tablo 1'de verilmiştir. 
Tablo 1. İş Güvencesizliğinin Etkilediği Tutum ve Davranışlar (Sverke vd., 2002, s.244.)

\begin{tabular}{lll}
\hline & Bireysel & Örgütsel \\
\hline \multirow{2}{*}{ Kısa } & İş Tutumları & Örgütsel Tutumlar \\
Dönem & İş Tatmini & Örgütsel Bağlılık \\
& İs bağlılık & Güven \\
\hline \multirow{2}{*}{ Uzun } & Sağlık & İşle İlgili Davranışlar \\
Dönem & Fiziksel Sağlık & Performans \\
& Zihinsel Sağlık & Kurumdan Ayrılma Niyeti \\
\hline
\end{tabular}

Bireysel ve örgütsel sonuçlarının yanında iş güvencesizliği hukuki açıdan da önemlidir. Ancak hukuki açıdan iş güvencesizliği, çalışanların işinin güvenceye alınması kapsamında önem kazanmaktadır. Türkiye'nin de onayladığı Uluslararası Çalışma Örgütünün Hizmet İlişkisine Son Verilmesi Sözleşmesine göre; işçinin kapasitesine veya işin yürütülmesine veya işyeri gereklerine dayalı geçerli bir sebep olmadıkça hizmet ilişkisine son verilemez. Ülkemizde işçilerin çalışma şartları ve çalışma ortamına ilişkin hak ve sorumlulukları da 4857 Sayılı İş Kanununa göre düzenlenmiştir.

\section{İş Performansı}

Performans, Tutar ve Altınöz (2010)'e göre; planlanmış bir etkinliğin amaca ulaşma derecesidir. İş performansı ise çalışanların işletme hedeflerine yönelik nicel ya da nitel katkısıdır (Celep, 2010). Altaş ve Çekmecelioğlu (2015) ise işletme performansını çalışanların görevlerini gerçekleştirmek için yapmış olduğu eylemler, harcamış olduğu çaba ile birlikte bu çaba ve eylemler sonucunda görevlerini gerçekleştirme ya da hedeflerine ulaşma derecesi şeklinde tanımlamıştır. Ancak, iş performansı, örgütteki bireyler tarafından farklı şekilde algılanabilir. Diğer bir anlatımla, somut tek bir iş performansından ziyade, taraflarca kabul edilen farklı iş performansı algılamaları ortaya çıkabilmektedir. Öyle ki; iş dünyasında çok çeşitli sektör ve faaliyet alanı söz konusudur ve başarı kriterleri değerlemesi çok geniş bir yelpazeye dağılmaktadır. Bu nedenle iş performansının ölçümü öznel bir nitelik taşıyabilir. Yani, hem işgören 
hem de yönetici, iş performansının düzeyini kendi bakış açısından farklı şekilde değerlendirebilir. Arzu edilen durum, her iki tarafın da iş performansını değerlendirmesinin birbirine benzeme oranının yüksek düzeyde olmasıdır. Yine de iş performansının kavramsallaştırılmasında öznel nitelik taşıyan genel kabuller bulunmaktadır.

İş gören performansının işe odaklanma, yetkinlik ve adanmışlık olmak üzere üç boyutu bulunmaktadır (Paşa, 2007, s.84). Odaklanma, çalışanın ne yapacağını bilmesi ve kendisini işe vermesi; yetkinlik, çalışanın bunu yapabilecek becerilere sahip olması; adanmışlık ise çalışanın katkıda bulunmaya istekli olmasıdır (Çekmecelioğlu ve Pelenk, 2015, s.148).

Tablo 2. İş Performansını Artırmak İçin Yönetim Kademesi Tarafından Alınabilecek Önlemler (Koçel, 2011, s.504-509; Pekdemir, Koçoğlu ve Gürkan, 2014, s.336-337; Valibayova,2018, s.58-59)

\begin{tabular}{|c|c|c|}
\hline Uygun ücretlendirme & Açık sözlülük & İşletme içi etkinlikler \\
\hline Özerklik & İlgi & $\begin{array}{l}\text { Ödüllendirme- } \\
\text { cezalandırma }\end{array}$ \\
\hline Daha fazla yetki & Esneklik & Adaletli terfi \\
\hline Fikirlerinin dinlenmesi & Objektif performans takibi & $\begin{array}{l}\text { Uygun ekonomik } \\
\text { teşvikler }\end{array}$ \\
\hline Şeffaflık & Yapıcı geri bildirimler & $\begin{array}{l}\text { Örgütün yapısal } \\
\text { özellikleri }\end{array}$ \\
\hline $\begin{array}{l}\text { Uygun fiziksel çalışma } \\
\text { ortamı }\end{array}$ & $\begin{array}{l}\text { İşleri kolaylaştıracak } \\
\text { ekipmanlar }\end{array}$ & $\begin{array}{l}\text { Geçerli sistem } \\
\text { ve prosedürler }\end{array}$ \\
\hline $\begin{array}{l}\text { Objektif denetim } \\
\text { uygulamaları }\end{array}$ & $\begin{array}{l}\text { Kurumsallaşma } \\
\text { ve profesyonelleşme }\end{array}$ & $\begin{array}{l}\text { Başarı değerlendirmede } \\
\text { objektiflik }\end{array}$ \\
\hline $\begin{array}{l}\text { Doğru insanlar } \\
\text { doğru işlerde çalıştırmak }\end{array}$ & $\begin{array}{l}\text { İş paylaşımı ve iş akışında } \\
\text { denge ve düzen }\end{array}$ & $\begin{array}{l}\text { Parçası olmaktan } \\
\text { gurur duyulacak iş ortamı }\end{array}$ \\
\hline Etkin bir iletişim sistemi & Ekip çalışması ve ruhu & Uygun çalışma saatleri \\
\hline $\begin{array}{l}\text { Güncel } \\
\text { teknolojinin kullanılması }\end{array}$ & $\begin{array}{l}\text { Uygulanması gerekli } \\
\text { kurallar }\end{array}$ & $\begin{array}{l}\text { Adil performans } \\
\text { değerlemeleri }\end{array}$ \\
\hline $\begin{array}{l}\text { Çalışanlara ve } \\
\text { işlerine sayg1 }\end{array}$ & İşyeri desteği & $\begin{array}{l}\text { Net ve açık } \\
\text { görev tanımları }\end{array}$ \\
\hline $\begin{array}{l}\text { Benimsenmiş } \\
\text { amaç ve hedefler }\end{array}$ & Kişiler arasındaki uyum & Eğitim ve motivasyon \\
\hline
\end{tabular}


Bireysel düzeyde yüksek iş performansının, örgütsel düzeyde yüksek performans sağlayacağı varsayılmaktadır. İş performansını olumlu yönde etkileyebilecek birçok faktör söz konusudur. Yılmaz ve Tanrıverdi (2017, s.46) tarafından belirtilen hususlara göre algılanan örgütsel destek iş performansını pozitif olarak etkilemektedir. İş arkadaşlarının ve yöneticilerin desteklediği, ödüllerin ve iş yükünün adaletli olarak dağıtıldığı bir örgüt ortamı, iş performans düzeyini arttırmaktadır. Diğer bir anlatımla iş ortamının özelliği, iş performansını etkilemektedir. Dolayısıyla çalışanların performansı örgütün performansını örgütün rekabet gücünü etkilmektedir (Turunç, 2010, s.54). Yöneticiler, çalışanların iş performansını artırmak için Tablo 2'de verilen önlemleri alabilir (Koçel, 2011, s.504-509; Pekdemir, Koçoğlu ve Gürkan, 2014, s.336-337; Valibayova, 2018, s.58-59).

Kısaca; iş performansı örgüt için önemlidir. Çünkü performans; örgütün stratejik planlaması, ücret-maaş artışı, kariyer planlaması, eğitimi ile eleman seçme, işten ayırma ve terfi gibi yönetim kararlarının alınmasını etkilemektedir.

İnsanın üretim faktörleri içindeki yeri günümüz bilgi ve teknoloji şartlarında daha belirgin bir şekilde ortaya çımıştır. İnsan faktörünün örgüt performansına olumlu etkisi olması için öncelikle kendisinin üstün performans göstermesi, bunun için de kurum kimliğini benimsemesi, kendisini gelecekteki muhtemel başarının etkin mimarları arasında görmesi ile gerçekleşir.

\section{Örgütsel Kimlik}

Örgüt çalışanları, örgütleriyle bütünlük içinde olmak ve kendilerini diğer örgütlerin çalışanlarından farklı konumlandırmak, çalıştıkları örgütün kendileri için ayırt edici olmasını ister. İnsanlar kendilerini geçmişte aileleriyle, isimleriyle ya da yaptıkları işlerle tanımlarken, günümüzde çalıştıkları örgüt ile tanımlamaktadır.

Örgütsel kimlik kavramı iş performansı ve iş güvencesizliği kavramı gibi ulusal ve uluslararası yazında oldukça fazla araştırılmış bir olgudur. Örgütsel kimlik, "Hangi örgüt, neyi, nasıl yapıyor?” sorusunun cevabını verir. Örgütsel kimlik, Marwick ve Fill (1997)'e göre örgütün kendisini diğer örgütlerden farklılaştırmak için kullandığı bir araç ve kendisini farklı paydaşlara sunuş şeklidir. Empson (2004)'e göre örgütsel kimlik, 
örgüt elemanlarının sosyal bir grup olarak kendilerini nasıl tanımladığı ve diğer örgüt elemanlarından kendilerini nasıl farklı gördüğü ile ilgilidir. Ak (1998) örgütsel kimliği, bir firmanın veya örgütün, bir hizmet veya ürünün adının, yaptığı işin, bu işin yapılışındaki anlayışın, görsel ve fikirsel olarak zihinlerde, olumlu-olumsuz, başarılı-başarısız, güzel-çirkin olarak yerleşmiş şekli, olarak tanımlamıştır.

Örgütsel kimlik, sosyal bir olgudur ve çeşitli unsurlardan oluşmaktadır. Bu unsurlar Korkmaz (2007)'a göre; örgüt çalışanlarının davranışları, örgütün felsefesi, iletişim biçimi ve görselliktir. Bu unsurlar, örgütlerin birbirleri ile farklılıklarını ortaya koymasına ve tanınmasına imkân vermektedir. Örgüt kimliği bir örgütün karakteri, kişiliği, temel biçimi ve özelliğidir. Bahsedilen bu unsurlar, örgütü tanımlar, şekillendirir ve yönlendirir (Downey, 1987, s.7).

Örgütsel kimlik, örgütün yaptığı bütün faaliyetler şeklinde tanımlanabilir (Şanlı ve Arabacı, 2016) ve bir kuruluş, işletme ya da organizasyonun kimliğini ifade eder (Okay, 2012, s.25). Kurum kimliği, bir örgütün üyelerinin kim olduğunu ve neyi temsil ettiğini nasıl algılayıp anladığıdır. Kurum kimliği, mesajların alıcısı olan örgüt üyelerinin bakış açısında görülür (Bronn, 2010, s.307).

Kurum kimliği unsurlarl; kurum felsefesi, kurumsal davranış, kurumsal görünüm, kurumsal iletişim ve kurumsal kaliteden oluşmaktadır (Derin ve Demirel, 2010, s.158). Kurum kimliği; kurumun işini, yapısını, stratejisini, değerlerini, pazarını, performansını, tarihini ve itibarını, diğer kurumlarla olan ilişkisi de dahil olmak üzere bir dizi sorunun ele alınmasını içermektedir (Balmer, 2001, s.257).

Kurumların bireyler gibi, kendilerini ifade etmelerinde kurum kimliği önemli bir rol oynamaktadır (Koçer, 2017, s.756). Kurum kimliğinin tanımlanmasında yedi ana boyut kullanılmaktadır (Melewar ve Karaosmanoğlu, 2006, s.849). Bu yedi ana boyut; kurumsal iletişim, kurumsal tasarım, kurumsal kültür, kurum davranışı, kurumsal yapı, endüstri kimliği ve kurumsal stratejidir. Bu ana boyut ve alt unsurları Şekil 1 'de gösterilmiştir. 


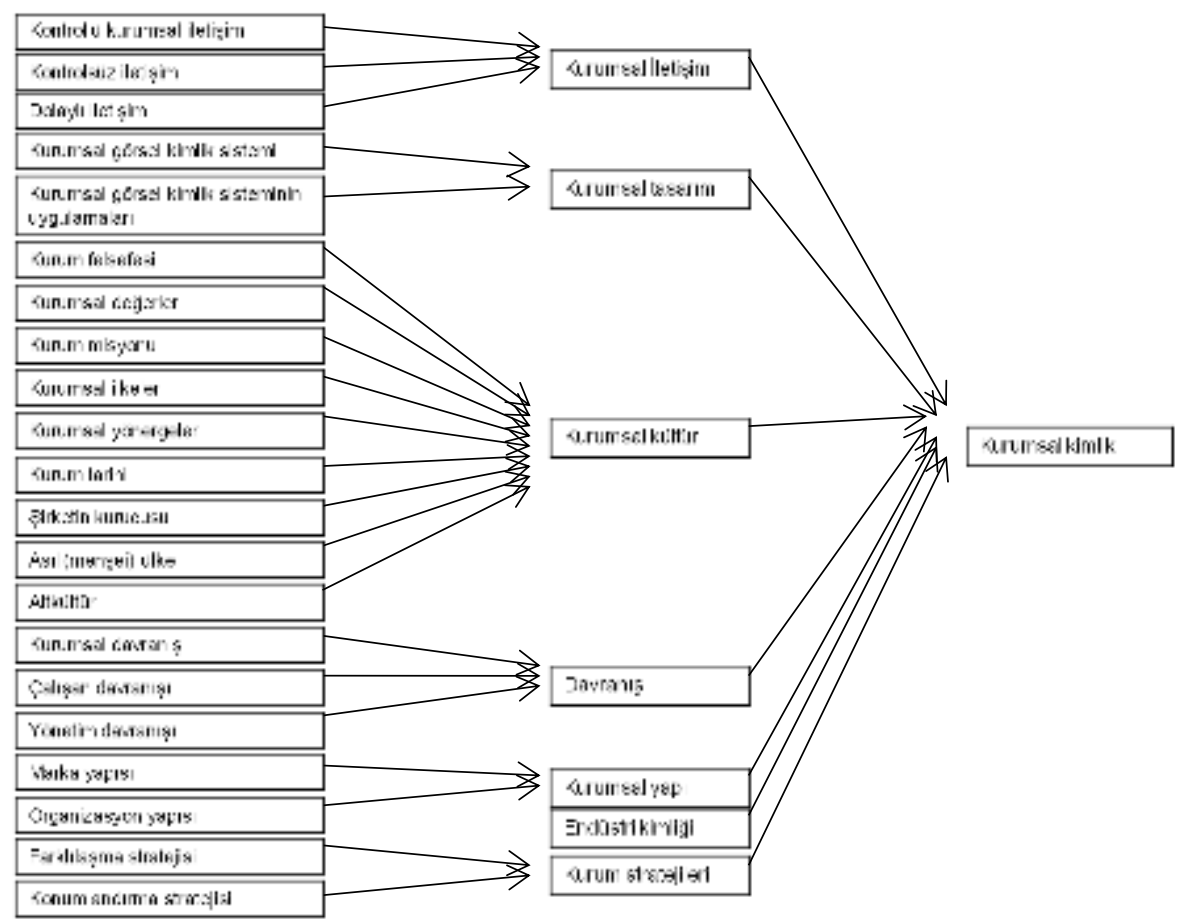

Şekil 1. Kurumsal Kimliğin Boyutları (Melewar ve Karaosmanoğlu, 2006, s.849)

Örgüt içindeki hiyerarşik farkl1lıklar, örgüt üyelerinin örgüt kimliğinin algılanmasında da farklılık gösterebilir. Bir örgütün en üst yönetim kademesi ile üretim atölyesindeki bir işçi örgütsel kimliği farklı şekilde algılayabilir. Her çalışanın farklı bir örgüt kimliği tanımı; farklı bir düşünce ve hissi olabilir. Ancak ortak düşünce ve his ile ortak özelliklerin toplamı örgütsel kimliği oluşturur. Bu durum her örgüt için farklılık gösterdiği için, hiç bir örgüt birbirine benzemez.

Örgütsel kimlik, örgütün üst yönetim kademeleri nezdinde diğer stratejik yönetim faaliyetlerinden ayrı tutulmadan, tıpkı diğer önemli yönetim kararları gibi planlanmalı yönetilmeli takip ve kontrol edilmeli gerektiği zamanlarda yeniden şekillendirilmelidir.

Her örgütün kendine has değerleri ve inancı vardır. Örgüt kimliği, örgüt ve çevresi tarafından paylaşılan tüm değerlerin ve inançların bir ifadesidir. Örgüt misyonu ve merkez kabul edilen değerleri aynı kalabilir 
fakat örgütsel kimlik değişen çevre faktörleri ile sabit kalmayabilir (Tüzün, 2006, s.57).

Literatürde yapılan araştırma neticesinde; iş güvencesizliğinin çalışanların iş performansını negatif yönde (Cheng ve Chan, 2008) etkilediği; iş güvencesizliği ile örgütsel kimlik (Piccoli vd., 2016), örgütsel kimlik ile iş performansı arasında (Ashfort vd., 2008) çeşitli araştırmaların yapıldığı görülmüştür.

İş güvencesizliği ile performans arasında ilişkiyi araştıran çalışmalarda farklı sonuçlar elde edilmiştir (Çakır, 2007, s.133). Şöyle ki; işsizlik kaygısının, işsiz kalmanın sonuçlarından kaçınan çalışanın çabasını ve performansını arttırdığı bulgusuna ulaşan araştırmalar da mevcuttur. Başka iş olanaklarının yetersiz ve bireyin işe finansal bağımlılı̆̆ının yüksek olduğu durumlarda, bireyler işte kalabilmek için çaba göstermektedir ve performansını artırmaktadır. İş güvencesizliği kaygısı performansta artışa yol açsa bile, uzun dönemde iş doyumu, işe bağll1ık, örgütsel bağlllık ve diğer tutumlarda da olumsuz etki yarattığı tespit edilmiştir.

İsaoğlu (2004)'nun tespitine göre iş performansının; iş güvencesizliği algısı ile olan ilişkisi negatif yöndedir. Chirumbolo ve Areni (2005) de iş güvencesizliğinin iş performansını olumsuz yönde etkilediğini tespit etmiştir. Çelebi (2017, s.115)'ye göre bireylerin performans düzeyleri ve iş güvencesi düzeyleri arasında pozitif yönlü ve zayıf bir ilişki vardır. Valibayova (2018, s.107) benzer şekilde iş güvencesizliği ile iş performansı arasında orta seviyede anlamlı ve pozitif bir korelasyon tespit etmiştir. Gültekin (2019) ise algılanan iş güvencesizliğinin performansı etkilemediği tespit edilmiştir.

\section{Uygulama}

Uygulama Kırıkkale ilindeki Makine Kimya Endüstrisi Kurumu (MKEK) Pirinç Fabrikasında yapılmıştır. MKE Pirinç Fabrikası demir dışı metallerin üretimi sektöründe Türkiye'de kurulan ilk fabrikadır. Fabrikada bakır, bronz, çeşitli pirinç malzemeler ve yüksükler ile ağır silah mühimmatı için sevk çemberleri ve kovan pulları üretilir (MKEK, 2019). 


\section{Çalışmanın Amacı}

$\mathrm{Bu}$ çalışma, iş güvensizliğinin iş performansını nasıl etkilediğini ve bu etkide örgütsel kimliğin aracilık rolünün bulunup bulunmadığını tespit etmek amacıyla yapılmıştır. Ulusal yazında iş güvencesizliği algısının; iş tatmini, iş performansı ve birey-örgüt arasındaki uyumu (Şimşek-Ilkım, ve Derin, 2018), çalışanların kaygı düzeyi (Dursun ve Bayram, 2013), tükenmişlik ve içsel işten ayrılma (Özbucak Albar, 2018) gibi çeşitli konuları inceleyen bazı araştırmalara rastlanmasına rağmen, iş güvensizliği kavramı ile iş performansı kavramı arasındaki ilişkide örgütsel kimlik kavramının aracilık rolünü inceleyen herhangi bir çalışmaya rastlanmamıştır. Dolayısıyla belirtilen iki değişken arasındaki örgütsel kimlik kavramının aracılık rolünün incelenmesi ilk olması nedeniyle önem arz etmektedir ve yapılan çalışmanın yazına katkı sağlayacağı değerlendirilmektedir.

\section{Yöntem}

Yapılan çalışmada kullanılan veriler, 01 Ocak 2016 - 01 Ocak 2017 tarihleri arasında MKE Pirinç Fabrikası Müdürlüğünde çalışan 105 personele yüz yüze görüşülerek uygulanmış üç ölçekten oluşan bir anket formu ile elde edilen birincil verilerdir. Algılanan iş performansı ölçeği Bush, Bush, Ortinau ve Hair (1990) tarafından geliştirilmiş ve Erkuş ve Fındıklı (2013) tarafından Türkçe'ye tercüme edilerek uyarlanmıştır. Ölçekte üç soru yer almaktadır, ancak ölçeğin geçerliliği kapsamında araştırma amacı doğrultusunda ihtiyaçtan dolayı bir soru ekleme yoluna gidilmiştir. Örgütsel kimlik ölçeği Mael ve Ashforth (1992) tarafından geliştirilmiş ve Türkçe geçerlemesi makalenin yazarları tarafından yapılmıştır. Bu kapsamda; ölçek geçerleme kurallarına uygun olarak; ölçeğin İngilizce-Türkçe ve Türkçe-İngilizce çevirileri alanında yetkin kişilerle birlikte yapılmış ve pilot uygulama asıl örneklem üzerinde gerçekleştirilmiştir. Ölçekte altı soru yer almaktadır. İş güvencesizliği ölçeği Isaksson, Hellgren ve Pettersson (2013) tarafından geliştirilmiş, Dereli (2012) tarafından Türkçe'ye uyarlanmıştır. Ölçekte üç soru yer almaktadır, ancak ölçeğin geçerliliği kapsamında araştırma amacı doğrultusunda ihtiyaçtan dolayı bir soru ekleme yoluna gidilmiştir. Kullanılan ölçeklerin geçerlilik çalışmaları ile 
kurulan modelin test edilmesinde doğrulayıcı faktör analizi ve yapısal eşitlik modellemesi (YEM) yöntemleri kullanılmıştır. Söz konusu yöntemlerin kullanılmasinda ise SPSS ve AMOS paket programından yararlanılmıştır.

\section{Çalışmanın Sınırlılıkları}

Örneklemin sadece bir kamu kurumundan seçilmiş olması, özel sektörde faaliyet gösteren işletmelerin araştırmaya dahil edilmemesi araştırmanın önemli kısıtlarından biridir. Değişkenler arasındaki ilişkiyi saptamak için sadece anket yöntemi ile elde edilen veriler kullanılmıştır. Bu durum, araştırmanın bulgularını sınırlandırmaktadır. Yine değişkenler arasındaki ilişkinin analizinde Yapısal Eşitlik Modellemesi kullanıldığından, bulgular bu kapsamda değerlendirilmelidir.

\section{Bulgular ve Tartışma}

Bu bölümde, önce örneklem, müteakiben örneklemden elde edilen veriler doğrultusunda oluşturulan model ile ilgili analizler hakkında bilgi verilmiştir. Bu kapsamda; her bir değişkenle ilgili doğrulayıcı faktör analizi yapılmış, değişkenler arasındaki korelasyon belirlenmiş, hipotezler yapısal eşitlik modeli ile test edilmiş ve elde edilen sonuçlar doğrultusunda öneriler sunulmuştur.

\section{Demografik Bilgiler}

Tablo 3. Ankete Katılanlarn Demografik Bilgileri

\begin{tabular}{|c|c|c|c|}
\hline Özellikler & Frekans & Özellikler & Frekans \\
\hline Cinsiyet & $\begin{array}{l}\text { Bay:95 kişi } \\
\text { Bayan:10 kişi }\end{array}$ & Eğitim Durumu & $\begin{array}{l}\text { İlkokul:30 kişi } \\
\text { Ortaokul:37 kiş̧ } \\
\text { Lise:33 kişi } \\
\text { Ünivesite:5 kişi }\end{array}$ \\
\hline Yaşı & $\begin{array}{l}\text { 21-30:27 kişi } \\
\text { 31-40:35 kişi } \\
\text { 41-50:31 kişi } \\
\text { 51-60:12 kişi }\end{array}$ & Pozisyonu & $\begin{array}{l}\text { Yönetici:4 kişi } \\
\text { Çalışan:101 kişi }\end{array}$ \\
\hline
\end{tabular}


Araştırmaya katılan 105 kişiye ait demografik bilgiler Tablo 3'te sunulmuştur.

\section{Araştırma Modeli ve Hipotezler}

Çalışmada kullanılan iş performansı, iş güvencesizliği ve örgütsel kimlik değişkenleri arasında ilişkiyi gösteren araştırma modeli Şekil-2'de sunulmuştur. Araştırma modelinde iş güvensizliği değişkenin iş performansı değişkenin üzerinde, iş güvensizliği değişkenin örgütsel kimlik değişkeni üzerinde ve örgütsel kimlik değişkeninin iş performansı değişkeni üzerinde etkisi ile iş güvensizliği değişkeni ile iş performansı değişkeni arasındaki ilişkide örgütsel kimlik değişkeninin aracılık etkisinin bulunabileceği gösterilmiştir.

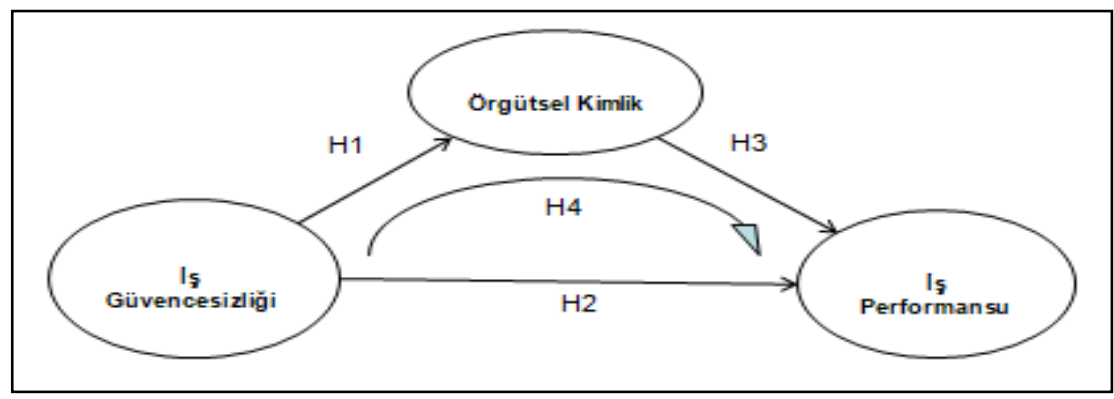

Şekil 2. Araştırma Modeli

Bu kapsamda Şekil-2'de sunulan modelde değişkenler arasındaki ilişkilerle ilgili dört adet hipotez kurulmuştur.

- $\quad H_{1}$ :Çalışanların iş güvencesizliği düzeyi ile örgütsel kimlik arasında anlamli ve negatif yönlü bir ilişki vardır.

- $\mathrm{H}_{2}$ :Çalışanların iş güvencesizliği ile iş performansı algısı arasında anlamlı ve negatif yönlü bir ilişki vardır.

- $\mathrm{H}_{3}$ :Örgütsel kimlik ile çalışanların iş performansı algısı arasında anlamlı ve pozitif yönlü bir ilişki vardır.

- $H_{4}$ :Çalışanların iş güvencesizliği ile iş performansı algısı arasındaki ilişkide örgütsel kimliğin aracılık rolü vardır. 
Çalışmada Kullanılan Ölçeklerin Doğrulayıcı Faktör Analiziyle Yapısal Geçerliğinin Kontrolü

Çalışmada kullanılan ölçeklerin yapısal geçerliğini kontrol etmek amacıyla doğrulayıcı faktör analizi (DFA) yapılmıştır. Bu kapsamda iş güvencesizlik ölçeği, iş performansı ölçeği ve örgütsel kimlik ölçeği ile ilgili olarak elde edilen DFA analizi sonuçları Şekil-3,4,5'de, söz konusu ölçeklerin uyum iyilik değerleri Tablo-4'te gösterilmiştir.

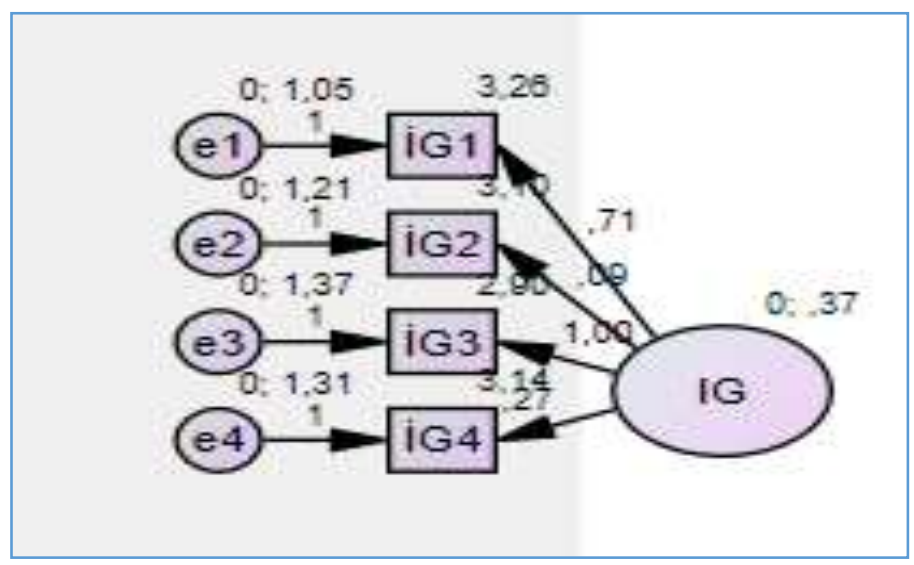

Şekil 3. İş Güvencesizlik Ölçeğinin DFA Analizi

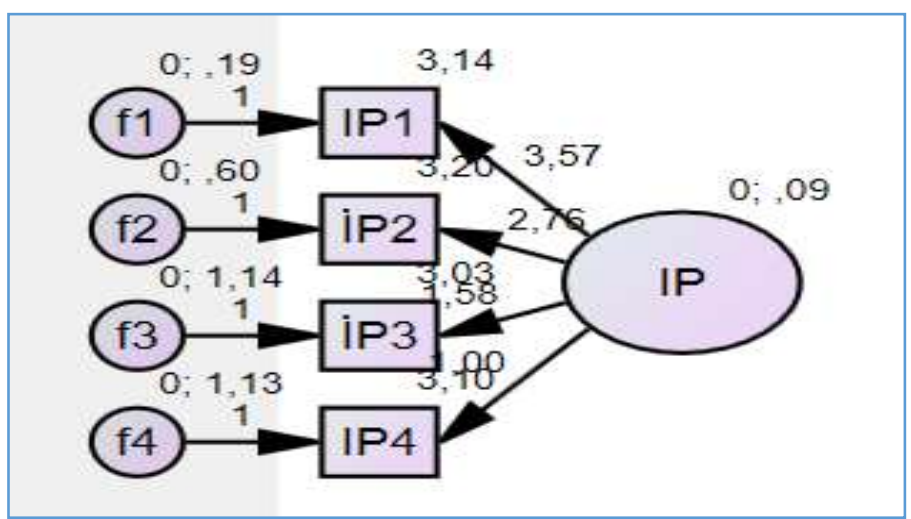

Şekil 4. İ̧̧ Performansı Ölçeğinin DFA Analizi 


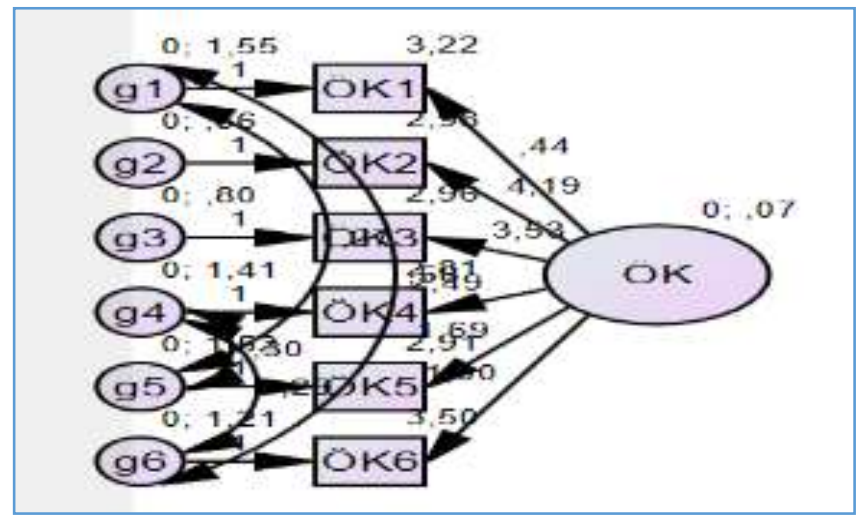

Şekil 5. Örgüt Kimliği Ölçeğinin DFA Analizi

Tablo 4. Çalışmada Kullanılan Ölçeklerin Uyum Değerleri

\begin{tabular}{llllllll}
\hline Ölçek & $\chi \mathbf{2}$ & sd & $\chi \mathbf{2 / s d}$ & RMSEA & CFI & GFI & NFI \\
\hline İş Güvencesizlik Ölçeği & 1,84 & 2 & 0,92 & 0,01 & 1 & 0,97 & 0,987 \\
İş Performansı Ölçeği & 2,912 & 2 & 1,456 & 0,066 & 0,989 & 0,987 & 0,968 \\
Örgüt Kimliği Ölçeği & 12,310 & 5 & 2,462 & 0,019 & 0,938 & 0,957 & 0,907 \\
\hline
\end{tabular}

p>0,05; RMSEA:Root Mean Square Error of Approximation (Yaklaşık Hataların Ortalama Karakökü); CFI:Comparative Fit Index (Karşılaştırmalı Uyum Indeksi); GFI:Goodness of Fit Index (ilyilik Uyum Indeksi); NFI:Normed Fit Index (Normlaştırılmış Uyum Indeksi)

Tablo 4'te verilen değerlerin, uyum referans değerlerine göre Kabul edilebilir sınır değerleri içinde olduğu tespit edilmiştir (Şimşek, 2007; Bayram, 2010). Bu kapsamda her üç ölçeğin tek yapılı olduğu ve çalışmada kullanılan örneklemlerde kullanılabileceği değerlendirilmektedir.

\section{Değişkenler Arasındaki İlişkinin İncelenmesi}

Tablo 5. Değişkenlere Ait Ortalama ve Standart Sapma Değerleri

\begin{tabular}{|c|c|c|c|c|c|c|}
\hline & & ORT & SS & $\begin{array}{l}\text { İş } \\
\text { Güvencesizliği }\end{array}$ & $\begin{array}{l}\text { Örgütsel } \\
\text { Kimlik }\end{array}$ & İş Performansı \\
\hline İş Güvencesizliği & $\begin{array}{l}\mathrm{r} \\
\mathrm{p}\end{array}$ & 3,06 & 1,56 & 1 & $\begin{array}{l}-0,560 \\
0,000 \\
\end{array}$ & $\begin{array}{l}-0,677 \\
0,00\end{array}$ \\
\hline Örgütsel Kimlik & $\begin{array}{l}\mathrm{r} \\
\mathrm{p}\end{array}$ & 2,39 & 2,72 & $\begin{array}{l}-0,560 \\
0,000 \\
\end{array}$ & 1 & $\begin{array}{l}0,533 \\
0,000 \\
\end{array}$ \\
\hline İş Performansı & $\begin{array}{l}\mathrm{r} \\
\mathrm{p}\end{array}$ & 1,19 & 1,93 & $\begin{array}{l}-0,677 \\
0,000\end{array}$ & $\begin{array}{l}0,533 \\
0,000\end{array}$ & 1 \\
\hline
\end{tabular}


Değişkenler arasındaki ilişkiyi gösteren korelasyon katsayıları ile söz konusu değişkenlere ait ortalama değerleri ile standart sapma değerleri Tablo-5'te yer almaktadır.

Evans (1996)'a göre; korelasyon değerleri "0.00-0.19: çok zayıf, 0.200.39: zayıf, 0.40-0.59: orta, 0.60-0.79: güçlü ve 0.80-1.00: çok güçlü" ilişkiyi göstermektedir ve çalışmada bu değerler esas alınmıştır. Bu kapsamda Tablo-5'te yer alan korelasyon değerleri incelendiğinde örgütsel kimlik ile iş performansı arasında anlamlı ve pozitif yönde kuvvetli, iş güvensizliği ile örgütsel kimlik ve iş güvensizliği ile iş performansı arasında anlamlı ve negatif yönde kuvvetli bir ilişkinin olduğu tespit edilmiştir. Dolayısıyla $H_{1}, H_{2}$ ve $H_{3}$ kabul edilmiştir.

\section{İş Güvencesizliği ile İş Performansı Arasında Örgütsel Kimliğin Aracılık Etkisinin Olmadığı Modelin Test Edilmesi (Model-1)}

Bu bölümde Şekil 6'da yer alan iş güvencesizliği ile iş performansı arasında örgütsel kimliğin aracılık rolünün olmadığı model test edilmiştir.

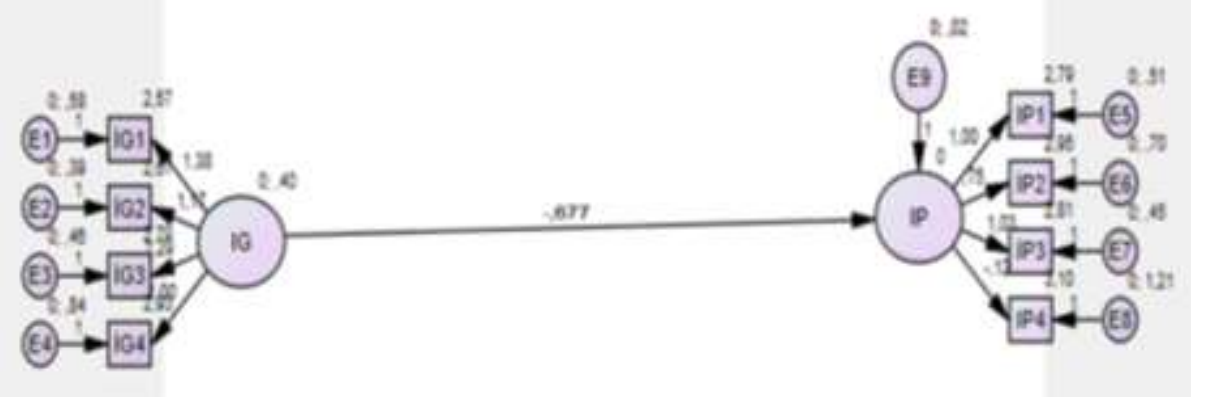

Şekil 6. Model-1'in Şekilsel Gösterimi

Test sonucunda kurulan modele ait uyum iyilik değerleri Tablo 6' da gösterilmiştir.

Tablo 6. Model-1'e Ait İstatistiki ve Uyum İyiliği Değerleri

\begin{tabular}{llllllllll}
\hline SRMR & GFI & AGFI & CFI & NFI & $\begin{array}{l}\text { NNFI } \\
\text { (TLI) }\end{array}$ & RMSEA & $\begin{array}{l}\text { CMIN/ } \\
\text { SD }\end{array}$ & $\mathbf{X}^{2}$ & $\mathbf{p}$ \\
\hline 0,04 & 0,97 & 0,93 & 0,91 & 0,94 & 0,91 & 0,04 & 1 & 2 & 0,04 \\
\hline
\end{tabular}


Tablo 6'da yer alan değerler incelendiğinde kurulan modele ait bütün uyum değerlerinin Tablo 4'te yer alan referans değerlerinin arasında ve anlamlı olduğu görülmüştür. Ayrıca iş güvencesizliği ile iş performansı değişkenleri arasında çizilen yola ait standardize edilmiş $\beta$ katsayısı, standart hatası ile anlamlılık düzeyi Tablo 7'de gösterilmiştir.

Tablo 7. Model-1'e ait Standardize Edilmiş $\beta$ Katsayısı, Standart Hatası ile Anlamlılık Düzeyi

\begin{tabular}{lllll}
\hline Yol & $\begin{array}{l}\text { Standardize } \\
\text { Katsayısı }\end{array}$ & $\boldsymbol{\beta}$ & Standart Hata & $\begin{array}{l}\text { Anlamlılık } \\
\text { Düzeyi }\end{array}$ \\
\hline $\begin{array}{l}\text { İş Güvencesizliği } \\
\text { İş Performansı }\end{array}$ & $-0,677$ & 3,54 & 0,000 \\
\hline
\end{tabular}

Tablo 7'de yer alan değerler, iş güvencesizliği ile iş performansı arasındaki yolun anlamlı olduğunu $(\beta=-0,677 ; p(0,000)<0,05)$ göstermektedir.

\section{İş Güvencesizliği ile İş Performansı Arasında Örgütsel Kimliğin Aracılık Etkisinin Olduğu Modelin Test Edilmesi (Model-2)}

$\mathrm{Bu}$ bölümde Şekil-7'de yer alan iş güvencesizliği ile iş performans1 değişkenleri arasında örgütsel kimliğin aracılık rolünün olduğu model test edilmiştir.

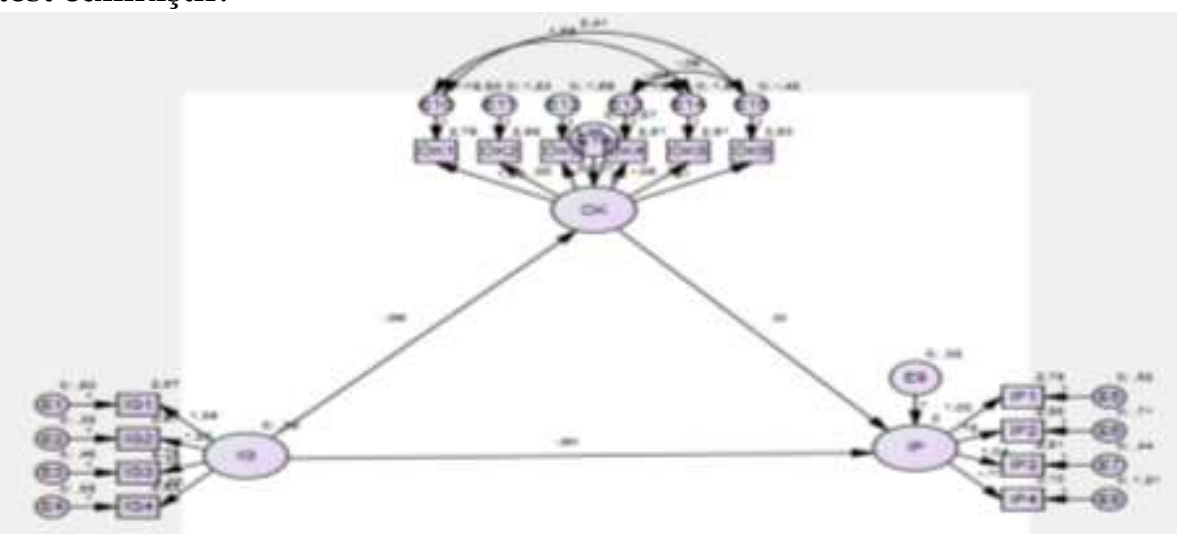

Şekil-7. Model-2'nin Şekilsel Gösterimi

Kurulan modele ait uyum iyilik değerleri Tablo 8'de gösterilmiştir. 
Tablo 8. Model-2'ye Ait İstatistiki ve Uyum İyiliği Değerleri

\begin{tabular}{llllllllll}
\hline SRMR & GFI & AGFI & CFI & NFI & $\begin{array}{l}\text { NNFI } \\
\text { (TLI) }\end{array}$ & RMSEA & $\begin{array}{l}\text { CMIN/ } \\
\text { SD }\end{array}$ & $\boldsymbol{X}^{2}$ & $p$ \\
\hline 0,02 & 0,94 & 0,93 & 0,91 & 0,88 & 0,96 & 0,07 & 2 & 2,14 & 0,04 \\
\hline
\end{tabular}

Tablo 8'de yer alan değerler incelendiğinde kurulan modele ait bütün uyum değerlerinin Tablo 4'te yer alan referans değerlerinin arasında ve anlamlı olduğu görülmüştür. Ayrıca iş güvencesizliği ile iş performansı arasında, iş güvencesizliği ile örgütsel kimlik arasında ve örgütsel kimlik ile iş performansı arasında çizilen yollara ait standardize edilmiş $\beta$ katsayıları, standart hataları ile anlamlılık düzeyleri Tablo 9'da gösterilmiştir.

Tablo 9. Model-2'ye ait Standardize Edilmiş Beta Katsayıları, Standart Hatalarn ile Anlamlilik Düzeyleri

\begin{tabular}{|c|c|c|c|}
\hline Yol & $\begin{array}{l}\text { Standardize } \\
\text { Beta Katsayisı }\end{array}$ & Standart Hata & Anlamlılık Düzeyi \\
\hline $\begin{array}{l}\text { İş Güvencesizliği } \rightarrow \\
\text { İş Performansı }\end{array}$ & $-0,671$ & 2,18 & 0,000 \\
\hline $\begin{array}{l}\text { İş Güvencesizliği } \rightarrow \\
\text { Örgütsel Kimlik }\end{array}$ & $-0,558$ & 2,14 & 0,012 \\
\hline $\begin{array}{l}\text { Örgütsel Kimlik } \rightarrow \\
\text { İş Performansı }\end{array}$ & 0,53 & 1,25 & 0,001 \\
\hline
\end{tabular}

Tablo 9'da yer alan değerler incelendiğinde; iş güvencesizliği değişkeninden örgütsel kimlik değişkenine ve örgütsel kimlik değişkeninden iş performansı değişkenine çizilen bütün yolların anlamlı olduğu $(\beta=-0,558$ ve $\beta=0,53 ; p(0,012 ; 0,001)<0,05)$ ve iş güvencesizliği değişkeninden iş performansı değişkenine çizilen yolun anlamlı olduğu $(\beta=-0,671$; $p(0,000)<0,05)$ ancak Model-2' deki standardize edilmiş $\beta$ katsayı değerinin Model-1'dekine göre düştüğü (Model-1: $\beta=-0,677$; Model-2: $\beta=-0,671$ ) tespit edilmiştir. Ayrıca Model-2'nin uyum iyiliği değerleri de Model-1'in uyum iyiliği değerlerine göre (Model-1: RMSEA=0,04; Model-2: RMSEA=0,07) kötüleşmektedir. Bu durumda, örgütsel kimlik değişkeninin iş güvencesizliği ile iş performansı değişkeni arasında kısmi aracılık rolüne sahiptir (Meydan ve Şeşen, 2011). 
İş güvencesizliği değişkeni ile iş performansı değişkeni arasında tespit edilen kısmi aracılık etkisinin anlamlı olup olmadığı Sobel Testi ile test edilmiştir. Çünkü yapılan test sonucunda tespit edilen azalma anlamlı değil ise değişkenler arasında kısmi aracılıktan bahsedilemez (Preacher ve Hayes, 2004). Yapılan Sobel Testi sonucunda iş güvencesizliği değişkeni ile iş performansı değişkeni arasında anlamlı bir ilişkinin bulunduğu $(z=3,23 ; p(0,018)<0,05)$ tespit edilmiştir. Dolayısıyla örgütsel kimliğin iş güvencesizliği değişkeni ile iş performansı değişkeni arasında kısmi aracılık etkisinin olduğu söylenebilir. Bu kapsamda dördüncü hipotez yani $H_{4}$ hipotezi kabul edilmiştir.

\section{Sonuç ve Öneriler}

Yapılan bu çalı̧̧mada, iş güvencesizliği değişkeni ile iş performansı değişkeni arasındaki ilişki ve bu ilişkide örgütsel kimliğin aracılık etkisinin olup olmadığı ampirik olarak test edilmek suretiyle araştırılmıştır. Çalışmanın analizinde değişkenler arasında ilişkide korelasyon katsayıları ve kurulan modelin test edilmesinde yapısal eşitlik modeli yöntemi kullanılmıştır. Çalışmanın sonunda örgütsel kimlik ile iş performansı değişkenleri arasında anlamlı ve pozitif yönde kuvvetli, iş güvencesizliği ile örgütsel kimlik ve iş güvencesizliği ile iş performansı değişkenleri arasında anlamlı ve negatif yönde kuvvetli bir ilişkinin olduğu ve iş güvencesizliği değişkeni ile iş performansı değişkeni arasında örgütsel kimlik değişkeninin kısmi aracılık etkisinin bulunduğu tespit edilmiştir.

İş güvencesizliği ve iş performansı arasındaki ilişkileri inceleyen araştırmalarda, iki değişken arasında negatif veya pozitif ilişki olduğunu tespit edenler olduğu gibi ilişki olmadığını tespit eden araştırma da vardır. Bu araştırma, bunlardan birincisini, yani iki değişken arasında anlamlı ve negatif bir ilişki olduğunu desteklemektedir.

Kırıkkale Pirinç Fabrikası Müdürlüğünde görev yapanların iş güvencesizliğine yönelik algıları arttıkça iş performansı azalmaktadır. Bu ilişkide örgütsel kimlik de etkilidir.

Küreselleşmiş olan dünyada işletmelerin ayakta kalabilmesi için insan faktörüne önem verilmesi, onun performansını artırıcı tedbirler alınması gerekmektedir. Yönetimden teşvik edici herhangi bir eylem görmeyen, 
kendi kariyerini geliştirme fırsatı tanınmayan, ücret artışı beklentisinin altında kalan, huzurlu bir çalışma ortamına sahip olmayan çalışanların iş performansı da düşük olacaktır.

Örgütsel kimlik, iş performansına olumlu katkı sağlamaktadır. Ancak iş güvencesi olmayan bir ortamda, çalışanlar örgütsel kimliği özümsemeyecektir. İş güvencesizliği arttıkça, örgüt kimliği çalışanlara bir şey ifade etmeyecektir.

Örgüt içinde kendi kararlarını alabilen, diğer personelin düşüncelerini önemseyen, birlik ve beraberlik hissini yaşayan ve yaşatan, iş yerindeki başarıdan kendine pay çıkarıp memnuniyet duyan, işyeriyle ilgili övgülerden mutlu olup, eleştirilerden incinen çalışanlar örgütsel kimlik çerçevesinde hareket etmektedir. Örgütsel kimlik çerçevesinde hareket eden kişilerin iş performansının da yüksek olacağı söylenebilir.

Çalışmanın Kırıkkale ilindeki Pirinç Fabrikası Müdürlüğünün personeline uygulandığı dikkate alındığında, diğer sektörlerde çalışanların iş güvencesizliğinin araştırılması elde edilen bulguların genellenebilirliğini artıracaktır. Ayrıca bu çalışma, beyaz yakalı ve mavi yakalı çalışanlar ile departmanlar bazında yapılabilir. Diğer taraftan iş performansının örgütsel sonuçlarına odaklanılması, bu davranışların örgütsel performansın artırılması yönündeki rolünün ortaya çıarılmasını sağlayacaktır. 


\section{EXTENDED ABSTRACT}

\section{The Mediation Effect of Organizational Identity in the Relationship between Job Insecurity and Job Performance}

Kenan Orçanl1 - Mustafa Bekmezci - Zafer Mehmet Fırat

National Defence University, Toros University, National Defence University (Guest Scholar)

Today, it is known by many researchers that organizational identity and job insecurity has an impact on job performance. As a result of research conducted in domestic and foreign literature; it was determined that relations between job performance, job insecurity and organizational identity were investigated, but it was not determined that the mediation effect of organizational identity was investigated in the relationship between job performance and job insecurity. The aim of this study is to determine whether organizational identity have a mediation role in the effect of job insecurity on job performance or not. The data used in the study were gathered with the three scales applied to the personnel of the Brass Factory Directorate in Kırıkkale province and the analysis of the model was tested with Structural Equation Modeling (SEM). The perceived job performance scale was developed by Bush, Bush, Ortinau and Hair (1990) and translated into Turkish by Erkuş and Findıklı (2013). Organizational identity scale was developed by Mael and Ashforth (1992) and its Turkish validity was made by the authors of the article. The job insecurity scale was developed by Isaksson, Hellgren and Pettersson (2013) and adapted to Turkish by Dereli (2012). The study population consisted of 105 employees working in the Brass Factory Directorate. As a result of this study, it was concluded that organizational identity has had a partial mediation role in the relationship between job insecurity and job performance. As a result of the Sobel Test conducted in relation to the relationships between the variables with partial mediating effect; it was confirmed that there was a significant 
relationship between job insecurity and job performance and that organizational identity had a partial mediation effect between two variables. In studies investigating the relationships between job insecurity and job performance, there are those who have found that there is a negative or positive relationship between the two variables and that there is no relationship. This study supports the first of these, namely that there is a significant and negative relationship between the two variables.

\section{Kaynakça / References}

Ak, M. (1998). Kurumsal kimlik ve imaj. İstanbul: Işıl Ofset Ltd.

Altaş, S.S. ve Çekmecelioğlu, H.G. (2015). Örgütsel adalet algısının iş tatmini, örgütsel bağlılık ve iş performansı üzerindeki etkileri: okul öncesi öğretmenleri üzerinde bir araştırma. İktisadi ve İdari Bilimler Dergisi, 29(3), 421-439.

Ashford, S.J., Lee, C. ve Bobko, P. (1989), Content, causes, and consequences of job insecurity: A theory based measure and substantive test, Academy of Management Journal, 4, 803-829.

Balmer, J.M.T. (2001). Corporate identity, corporate branding and corporate marketing - seeing through the fog. European Journal of Marketing, 35(3/4), 248-291.

Bayram, N. (2010). Yapısal eşitlik modellemesine giriş AMOS uygulamaları. Bursa: Ezgi Kitabevi.

Broon, P.S. (2010). Reputation, communication and the corporate brand. In (R. L. Heath Ed.), The Sage Handbook Of Public Relations (307-320), Los Angeles:S age.

Bush, R.P., Bush, A.J., Ortinau, D.J. ve Hair, J.F. (1990). Developing a behavior-based scale to assess retail salesperson performance. Journal of Retail, 66(1), 119-36.

Celep, H. (2010). Kamu sektöründe performans yönetimi ve ölçümü. Mesleki Yeterlilik Tezi. Strateji Geliştirme Başkanlığı, Ankara.

Cheng, G.H.L. ve Chan, D.K.S. (2008). Who suffers more from job insecurity? A meta-analytic review, Applied Psychology, 57(2), 272-303. 
Chirumbolo, A. ve Areni, A. (2005). The influence of job insecurity on job performance and Absenteeizm: The moderating effect of work attitudes. University "G. D'Annunzio" of Chieti-Pescara. Journal of Industrial Psychology, 31 (4), 65-71

Çakır, Ö. (2007). İşini kaybetme kaygısı: İş güvencesizliği. Çalışma ve Toplum, 1, 117-140.

Çekmecelioğlu, H.G ve Pelenk, S.E. (2015). Örgütsel engellerin, örgütsel bağlılık ve iş performansı üzerindeki etkileri: Kocaeli Lastik İşletmelerinde bir araştırma. KOSBED, 29, 143-164.

Çelebi, İ. (2017). İşletmelerde iş güvencesizliğinin tükenmişliğe ve performansa etkileri ve adıyaman bölgesindeki işletmelerde bir uygulama. Yayınlanmamış Yüksek Lisans Tezi. Harran Üniversitesi Sosyal Bilimler Enstitüsü, Şanlıurfa.

Dereli, B. (2012). İş güvencesizliği kavramı ve banka çalışanlarının iş güvencesizliğine yönelik algılarının demografik özelliklerine göre incelenmesi. İstanbul Ticaret Üniversitesi Sosyal Bilimler Dergisi 11(21), 237-256

Derin, N. ve Demirel, E.T. (2010). Kurum imajının kurum kimliği açısından açıklanabilirliği: İnönü Üniversitesi Turgut Özal Tıp Merkezi örneği. Hacettepe Sağllk İdaresi Dergisi, 13(2), 155-193.

De Witte, H. (1999). Job insecurity and psychological well-being: Review of the literature and exploration of some unresolved issues. European Journal of Work and Organizational Psychology, 8(2), 155-177.

Downey, S.M. (1986-1987). The relationship between corporate culture and corporate identity. Public Relations Quarterly, 31(4), 7-12.

Dursun, S. ve Bayram, N. (2013). İş güvencesizliği algısının çalışanların kayg1 düzeyleri üzerine etkisi: Bir uygulama, "Işs-Güç" Endüstri İlişkileri ve İnsan Kaynakları Dergisi, 15(3), 22-27.

Empson, L. (2004). Organizational identity change: Managerial regulation and member identification in accounting acquisition. Accounting, Organizations and Society, 29, 759-781.

Erkuş, A. ve Fındıklı, M.A. (2013). Psikolojik sermayenin iş tatmini, iş performansı ve işten ayrılma niyeti üzerindeki etkisine yönelik bir araştırma. İstanbul Üniversitesi İşletme Fakültesi Dergisi, 42(2), 302318. 
Evans, J.D. (1996). Straightforward statistics for the behavioral sciences. Pacific Grove. CA: Brooks/Cole Publishing.

Greenhalgh, L. ve Rosenblatt, Z. (1984). Job insecurity: Toward conceptual clarity. Academy of Management Review, 9(3), 438-448.

Gültekin, Z. (2019). İş güvencesizliğinin psikolojik iyi oluşa ve performansa etkisinde meslekî bă̆lılığın aracılık rolü. Yayınlanmamış Doktora Tezi. Gaziosmanpaşa Üniversitesi Sosyal Bilimler Enstitüsü, Tokat.

Isaksson, K., Hellgren, J. ve Pettersson, P. (1998), Strukturomvandling inom Svensk detaljhandel: Uppföljning av Omorganisation och Personalminskning i KF/KDAB [Structural transformation in Swedish retail trade: Follow-up of a reorganization and layoff in KF/KDAB]. Reports from the Department of Psychology, No. 97/1998. Stockholm University, Stockholm.

Şimşek-Ilkım, N. ve Derin, N. (2018). Algılanan iş güvencesizliği, iş tatmini ve birey-örgüt uyumu kavramları arasındaki ilişkiler, Sosyal Ekonomik Araştırmalar Dergisi, 18(36), 238-254.

İsaoğlu, F.G.. (2004) Özel sektör çalışanlarında iş güvencesizliğinin öz yeterlik ve iş performansı ile ilişkisi. Yayınlanmamış Yüksek Lisans Tezi. Hacettepe Üniversitesi / Sosyal Bilimler Enstitüsü, Ankara.

Koçel, T. (2011). İşletme yöneticiliği. İstanbul:Beta Basım Yayım.

Koçer, S. (2017). Kurumsal web sitelerinin kurum kimliği açısından incelenmesi: En çok tercih edilen üniversiteler üzerine bir analiz. Uluslararası Sosyal Araştırmalar Dergisi, 10(53),756-772.

Korkmaz, M. (2007). Örgütsel sağllk üzerinde liderlik stillerinin etkisi. Kuram ve Uygulamada Ĕ̆itim Yönetimi Dergisi, 49, 57-91.

Mael, F., ve Ashforth, B. E. (1992). Alumni and their alma mater: A partial test of the reformulated model of organizational identification. Journal of Organizational Behavior, 13, 103-123.

Marwick, N. ve Fill, C. (1997). Towards a framework for managing corporate identity. European Journal of Marketing, 31(5), 396-409.

Melewar, T.C. ve Karaosmanoğlu, E. (2006). Seven dimensions of corporate identity a categorisation from the practitioners' perspectives. European Journal of Marketing, 40(7/8), 846-869.

Meydan, C.H. ve Şeşen, H. (2011). Yapısal eşitlik modellemesi AMOS Uygulamaları. Ankara:Detay Yayımcilık. 
MKEK Pirinç Fabrikası Hakkında. 05 Mayıs 2019 tarihinde https://www.mkek.gov.tr/tr/page.aspx?id=69. adresinden erişildi.

Okay, A. (2012). Kurum kimliği. Ankara: MediaCat.

Olins, W. (2017). The new guide to identity: How to create and sustain change through managing identity, New York: A Gower Book.

Özaman-Boya, F. ve Demiral, Y. (2006). İş güvensizliği ve sağlık araştırmaları. Türk Tabipleri Birliği Mesleki Sağllk ve Güvenlik Dergisi, 7(27), 45-48.

Özbucak-Albar, B. (2018). İş güvencesizliği, tükenmişlik ve içsel işten ayrılma, Sosyal Bilimler Dergisi, 5(26), 164-174.

Paşa, M., (2007). Stresin bireysel performans üzerindeki etkileri ve bir uygulama. Yayınlanmamış Doktora Tezi. Uludağ Üniversitesi Sosyal Bilimler Enstitüsü, Bursa.

Pekdemir, I., Koçoğlu, M. ve Gürkan, G.Ç. (2014). Özerklik ve ödüllendirme algılarının çalışan performansı üzerindeki etkisinde çalışanın inovasyona yönelik davranışının aracılık rolüne yönelik bir araştırma. İstanbul Üniversitesi İşletme Fakültesi Dergisi,43 (2), 332-350.

Piccoli, B., Callea, A., Urbini, F., Chirumbolo, A., Ingusci, E. ve De Witte, H. (2016). Job insecurity and performance: The mediating role of organizational identification, Personnel Review, 46(8), 1508-1522.

Preacher, K.J. ve Hayes, A.F. (2004). SPSS and SAS procedures for estimating indirect effects in simple mediation models: Behavior research methods. Instruments, and Computers, 36, 717-731.

Sverke, M., Hellgren, J. ve Naswall, K. (2002). No security: A meta-analysis and review of job insecurity and it's consequences. Jourmal of Occupational Health Psychology, 7, 242-264.

Sverke, M., Hellgren, J., Naswall, K., Chirumbolo, A., Dewitte, H., ve Goslinga, S. (2004). The nature of job insecurity. In (M. Sverke, J. Hellgren, K. Naswall, A. Chirumbolo, H. De-Witte, S. Goslinga Ed.). Job Insecurity and Union Membership, (39-58), Brussels: SALTSA.

Şanlı, Ö. ve Arabacı, İ.B. (2016). Lise öğretmenlerinin örgütsel kimlik algılarının bazı değişkenler açısından incelenmesi. Bartın Üniversitesi Eğitim Fakültesi Dergisi, 5(2), 443-458. 
Şimşek, Ö.F. (2007). Yapısal eşitlik modellemesine giriş: Temel ilkeler ve LISREL uygulamaları. Ankara: Ekinoks Yayınları.

Turunç, Ö. (2010), Organizasyonlarda kontrol algılamalarının örgütsel özdeşleşme ve iş performansına etkisi. Cü İktisadi ve İdari Bilimler Dergisi, 11(1), 251-269.

Tutar, H. ve Altınöz, M. (2010), Örgütsel iklimin işgören performansı üzerine etkisi: OSTIMM imalat işletmeleri çalışanları üzerine bir araştırma. Ankara Üniversitesi SBF Dergisi, 65(2), 196-218.

Tüzün-Kalemci, İ. (2006). Örgütsel güven, örgütsel kimlik ve örgütsel özdeşleşme ilişkisi: Uygulamalı bir çalışma. Yayınlanmamış Doktora Tezi. Gazi Üniversitesi, Ankara.

Valibayova, G. (2018). İş güvencesizliği algısının işs stresi ve iş performansına etkisi: Araştırma görevlileri üzerine bir çalışma. Yayınlanmamış Yüksek Lisans Tezi. Ondokuz Mayıs Üniversitesi Sosyal Bilimler Enstitüsü, Samsun.

Yılmaz, A. ve Tanrıverdi, H. (2017). Aş̧̧ıların örgütsel destek algısının iş performansı üzerine etkisinde iş ortamı niteliğinin aracılık rolü. Journal of Tourism and Gastronomy Studies 5(3), 32-52.

4857 Numaralı İş Kanunu (2003). Resmi Gazete, (Sayı:25134). 05 Mayıs 2019 tarihinde $\quad$ http://www.resmigazete.gov.tr/eskiler/2003/06/ 20030610.htm. adresinden erişildi.

\section{Kullanılan Ölçekler}

Bu çalışmada kullanılan ölçekler aşağıda verilmiştir. Ölçekler 5'li Likert şeklindedir (1=Kesinlikle katılmıyorum, 3=Kararsızım, 5=Kesinlikle katıliyorum)

\section{İş Güvencesizliği Ölçeği}

1. İşyerimin yakın zamanda benim için teşvik edici bir iş içeriği sağlayacağını hissediyorum.

2. İşyerimde ileriye yönelik kariyer fırsatlarım ümit vericidir.

3. İşyerimde ücret artışım tatmin edicidir.

4. İş yerinde huzurum yerindedir.

İş Performansı Ölçeği

1. Görevlerimi kısa sürede tamamlarım.

2. Zamanımı bir çok çalışandan daha iyi yönetirim. 
3. İş performansım diğer çalışanlardan daha iyidir.

4. İş esnasında oldukça etkiliyimdir.

\section{Örgütsel Kimlik Ölçeği}

1. Örgüt içinde kendi kararlarımı alabilirim.

2. Diğer personelin ne düşündüğü önemlidir.

3. İş yerinde çalışanlar ile ilgili konuştuğumda "onlar" yerine "biz" diye hitap ederim.

4. İş yerinin başarısı benim başarımdır.

5. İş yeri birisi tarafından övülürse kişisel başarım gibi hissederim.

6. Medyada iş yeri eleştirildiğinde incinirim.

\section{Kaynakça Bilgisi / Citation Information}

Orçanlı, K., Bekmezci, M. ve Fırat, M.Z. (2019). İş güvencesizliğinin iş performansina etkisinde örgütsel kimliğin aracllık etkisi. OPUSUluslararası Toplum Araştırmaları Dergisi, 12(18. UíK Özel Sayısı), 73-100.DOI: 10.26466/opus.584655. 